\title{
Health care insurance in the Soviet Union
}

\author{
Michael Ryan
}

Though uncontrollable forces seem to threaten the constitutional break up of the Soviet Union, the central government headed by Mikhail Gorbachev continues to promulgate large scale changes, which are intended to be binding on all 15 republics. A case in point is the draft law entitled "The principles of legislation of the USSR and union republics on the financing of health care." Published towards the end of October 1990, this document embodies a fundamental ideological shift; it entails abandoning the formerly much vaunted principle of financing the provision of free services from the general revenues of the state.

In a sense this follows on from-while going far beyond - a radical modification of financial arrangements, which had been introduced by Yevgeni Chazov, USSR health minister until March 1990. That development, closely comparable with the introduction of an internal market in the British NHS, had been objected to by some people. Their hostility was acknowledged by Chazov in his address to the All-Union Congress of Doctors in October 1988 (see box).

Practical experimental schemes needed to be launched. But as the congress was told, the Russian Republic's health ministry, party, and Soviet organisations in Leningrad, Kuibyshev, and Kemerovo agreed to implement new forms of planning, financing, and managing the delivery of health care. The search for other strategies was being conducted elsewhere in the country and a commission had been established at the USSR Ministry of Health in order to summarise the results of the different schemes and draw conclusions.

Politically, however, it was necessary to adduce a powerful if not decisive refutation of the opinions to which Chazov had referred. In fact the passage quoted in the box achieves that objective by citing a supreme authority. It goes on:

A correspondent of one of the central newspapers who had not grasped the point of the matter even described such interrelationships as "trading in patients." I would like to call his attention to the classic works of Marxism-Leninism, or at least to Lenin's programme for the creation of hospital benefit funds [my italics].

\section{Beyond perestroika}

Hospital benefit funds require a brief explanation. This is a scheme of social insurance, which provided finance for medical care for a limited section of the urban population during the early years of the Soviet state. The insurance principle was finally discarded in 1936 in a major rationalisation programme that also included establishing the USSR Commissariat of Health.

Chazov's address does not contain any hint that the internal market would be a prelude to the far more radical arrangement whereby the cost of items of service would be met by insurance funds and individuals paying from their own pockets. But the government had already accepted the desirability of some medical establishments charging fees for their services, while the related notion of a system of prepayment through medical insurance was being discussed in the press.

Since that time the Soviet Union's political and

\section{Chazov speaking in 1988}

Moreover one hears categorical opinions that in such a humane sphere of our socialist society's activity as health care we should not count the money, link the process of treatment with a specific type of intradepartmental cost accounting, envisaging the use of material incentives for particular qualitative indicators of work, and we should not create mutual financial accounts between health care establishments.

economic position has gone from bad to very much worse. Attempts are being made to bring about a rapid but ordered transition to a market type economy. And widespread recognition of the screaming deficiencies of much of the health care provision - for which the state was responsible-presumably made it all the more likely that this sector would be identified for inclusion in the rush to the market.

The relevance of those broad background influences is clear in the introduction to the draft law.

The present law defines the general legal principles for financing the system of health care in the USSR in conditions of regulated market relations and diversity of forms of ownership.

\section{Whose ideas?}

As Meditsinskaya gazeta reported, the draft law was largely the brainchild of an ad hoc group, which included economists and jurists in addition to health care administrators. Only when the principal ideas had been elaborated was it scrutinised by the ministry's kollegiya-a sort of cabinet. I shall attempt to identify certain key features and underlying ideas of the document.

One unexpected feature of the proposed scheme is the built in arrangement for two tiers of provision. Patients would receive medical and pharmaceutical services free of charge up to the limits established by legislation, while anything above those limits would have to be paid for by the individual. It is impossible to say how basic the free element of the scheme would be without precise information on the maximum cash value or the items of service representing these limits. Common sense suggests, however, that there would be no point in legislating for a top up element which would exist only on paper.

Corroboration of that view can be found in an objective that is not explicit in any article of the draft law but, arguably, was top priority for the authors of it. This is the discovery of additional sources of finance for a sector of the economy which, as is now generally recognised, had long been handicapped by severe and chronic underfunding by the state.

\section{Increased revenue}

Financial resources for health care would be available from three separately identified sources. The first would be the network of health care funds, which would exist at all the main levels of the existing
Michael Ryan, PHD, lecturer 
administrative structure of the service: union, republican, regional, and district or town. Their sources of income would derive from whatever was allocated from the total state budget at the relevant level, and from voluntary, tax deductible contributions from employers ("enterprises, establishments and organisations"), whether in private or public ownership. Voluntary contributions could also be made by charitable funds and individual citizens.

Those funds can be seen as mainly serving to perpetuate the principle of funding health care from general tax revenue, and also justifying the assignment of responsibility for the organisation of the insurance system to the Soviets of people's deputies - that is, elected councils. The organisational details have yet to be decided and variants are set out in the draft law. All the same, the Soviets are clearly intended to play a central part in determining the level of the compulsory insurance contributions. (While all citizens will be covered by the scheme certain categories of the population will be temporarily or permanently exempt from contributing to it, as would be expected.)

\section{One unexpected feature of the proposed scheme is the built in arrangement for two tiers of provision.}

The second main source of health care finance is the contributions from employers, employees, and self employed persons and the associated creation of what are termed "insurance institutions." Incidentally, a striking use of economic incentives can be seen in the requirement that a higher level of contribution must be paid by those employers whose premises and working conditions create greater than normal health hazards. Another interesting feature is that employers would be empowered to make extra payments for their workforce to buy items of service that were not covered by compulsory insurance, presumably an attractive form of fringe benefit. In an analogous arrangement any individual may take out additional insurance at his or her own cost.

The third and final source of funding would be payments made directly to health service units by employers (and charitable funds) and by individuals. What services such moneys would buy is unclear from the opaque reference in the draft law to "measures for the protection of health and payment for medical services." Perhaps that envisages specially contracted items of service, such as additional health checks for a factory's employees.

\section{The Russian view}

Given the loss of central authority in the current political and economic turmoil, will the draft law be adopted or ignored by the heartland of the crumbling union? A report carried by Meditsinskaya gazeta makes clear that elected representatives in the Russian republic are indeed preparing to go down much the same road, but-and the point is crucial-entirely of their own choosing. At the end of October 1990 a select committee of the Russian Republic's Supreme Soviet gave preliminary consideration to two closely comparable schemes of medical insurance put forward by the republican health ministry and an initiative group headed by Deputy V I Mandrygin (a neurologist from Saratov).

Already well aware of the present problems, deputies listened to a gloomy prognosis of the immediate future from Professor Yu M Komarov, chairman of the health ministry's drafting group. According to Meditsinskaya gazeta, "The 24 tendencies which he enumerated in the health condition of the Russian people were threatening, one might say sinister.' Furthermore, it was learnt that the republic's finance ministry intended to allocate only 17 billion roubles for health care in next year's budget, as against the 24 billion which had been asked for. Not surprisingly, "the deputies were once again convinced that decisive and rapid action is needed."

In seeking a practical alternative to the apparent dead end of their existing system, Russian deputies had examined the experience of nine developed countries and visited two of them, Japan and the United States. They were aware, however, that foreign models had limited usefulness in Russia because of sharp differences in the levels of economic development, per caput income, and personal and communal hygiene. The difficulties of implementing the new system, they also recognised, would be exacerbated by the uneven development in different areas of Russia, the "absence of a single technology," and lack of appropriate staff training.

Nevertheless, deputies seem committed to implementing the scheme. It would be introduced first in the Kemerovo and Kuibyshev regions (see above), on the ground that they were best prepared to cope with the innovations. Step by step programmes for the transition to insurance medicine would be elaborated for each region; these would apparently be based on the following three principles: maximum decentralisation of financing and management, economic independence for establishments providing curative and preventive medical care, and the formation of a rational structure of medical care.

\section{A partnership envisaged}

If what can be called the new Russian principles for health care organisation are almost the antithesis of the traditional Soviet ones so also is the acceptance of an independent role to be played by doctors. Thus the medical associations are identified as partners of the authorities: they will be "co-implementors" of medical insurance. This notion will be realised not only in the technical task of elaborating tariffs, but, with far broader significance, in "the important function of controlling the quality of medical care."

As many Russians know to their cost, the existing system has had the effect of virtually negating doctors' responsibility for the end results of their action, or lack of action. The introduction of a compulsory insurance scheme may well have a strong reciprocal relationship with the developing professionalisation of medical practice.

1 Anonymous. Vsesoyuznyi s"ezd vrachei Moskva 17-19 oktyabrya 1988: materialy i stenogramma s"ezda. Moskva: Meditsinskaya entsiklopediya, 1989:22. * Ryan M. Doctors and the state in the Soviet Union. London: Macmillan Press, 1989:98-103

3 'Osnovy zakonodatel'stva SSSR i soyuznikh respublikh o finansirovaniya zdravookhraneniya', Meditsinskaya gazeta 1990:26 oktyabrya: 1-2. 4 Borich I. 'Strakhovoi polis, vyruchai!', Meditsinskaya gazeta 1990: 28 oktyabrya: 1.

${ }^{\star}$ I thank Dr John Cule for the gift of this book. 